\title{
Habitual Coffee Consumption Does Not Correlate with Blood Pressure, Inflammation and Endothelial Dysfunction but Partially Correlates with Oxidative Stress
}

\author{
Erizal Sugiono ${ }^{1,2, *}$, Mansyur Arief ${ }^{1}$, Anwar Santoso $^{3}$ \\ ${ }^{1}$ Postgraduate Program in Clinical Biochemistry, Hasanuddin University, Jl. Perintis Kemerdekaan Km.10, Makassar, Indonesia \\ ${ }^{2}$ Prodia the CRO, Prodia Tower $6^{\text {th }}$ Floor, Jl. Kramat Raya No.150, Jakarta, Indonesia \\ ${ }^{3}$ Udayana University, Bukit Jimbaran, Badung, Denpasar, Bali, Indonesia \\ *Corresponding author. E-mail: erizal.sugiono@prodia.co.id
}

\section{Abstract}

B ACKGROUND: Coffee is the most widely consumed beverage in the world and has been known to have effects on cardiovascular system. Many researchers have examined the effects of coffee consumption on blood pressure (BP) and risk of cardiovascular disease (CVD), but their results were inconsistent and still remain a subject of controversy. Oxidative stress, inflammation, and endothelial dysfunction have been known as risk factors of hypertension and CVD. Those factors are also known to be affected by coffee consumption. The aim of this study was to examine the relationship between the effects of habitual coffee consumption on BP and to examine the role of oxidative stress (F2 isoprostane), inflammation (high sensitive $\mathrm{C}$-reactive protein (hsCRP)) and endothelial dysfunction (asymmetric dimethylarginine (ADMA)).

METHODS: This was a cross-sectional study in which forty-seven healthy, non-smoking men aged 30-60 years with varying coffee-drinking habits were enrolled. BP and blood/urine analysis of biomarkers were measured in the morning before activity. Coffee consumption was assessed using a questionnaire. The differences among variables were analyzed using ANOVA and the correlations between variables were analyzed using Kendall's Tau correlation analysis.

RESULTS: Habitual coffee consumption did not correlate with systolic / diastolic BP ( $\mathrm{r}=-0.02 ; p=0.856$ and $\mathrm{r}=0.15$; $p=0.230$, respectively). Concentrations of ADMA and hsCRP were also not correlated with coffee consumption ( $\mathrm{r}=0.03 ; p=0.764$ and $\mathrm{r}=0.04 ; p=0.701$, respectively). Coffee

Abstrak

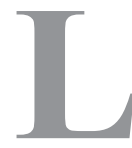

ATAR BELAKANG: Kopi adalah minuman yang banyak dikonsumsi di dunia dan diketahui memiliki pengaruh terhadap sistem kardiovaskular. Banyak penelitian telah dilakukan untuk melihat hubungan antara kebiasaan minum kopi dengan peningkatan tekanan darah (TD) dan risiko kejadian Penyakit Kardiovaskular (PKV), tetapi hasilnya tidak konsisten dan tetap menjadi perdebatan sampai saat ini. Stres oksidatif, inflamasi dan disfungsi endotel telah diketahui sebagai faktor risiko terjadinya hipertensi dan PKV. Faktor-faktor risiko tersebut diketahui dapat dipengaruhi oleh kebiasaan minum kopi. Tujuan penelitian ini adalah untuk mengkaji pengaruh kebiasaan minum terhadap TD, stres oksidatif (F2 isoprostan), inflamasi (high sensitive C-reactive protein (hsCRP)) dan disfungsi endotel (asimetrik dimetilarginin/ADMA).

METODE: Penelitian ini menggunakan metode potong lintang dengan jumlah subyek 47 orang pria dewasa yang sehat, berusia 30-60 tahun dengan bermacam tingkatan kebiasaan minum kopi. Pengukuran TD dan pemeriksaan parameter kimia dilakukan pada pagi hari sebelum aktivitas. Kebiasaan minum kopi diperoleh melalui pengisian kuisioner. Analisis perbedaan antara variabel penelitian dilakukan menggunakan ANOVA dan analisis hubungan antara variabel penelitian menggunakan metode Kendall's Tau.

HASIL: Kebiasaan minum kopi tidak berhubungan dengan TD sistolik dan diastolik $(\mathrm{r}=-0,02 ; p=0,856$ dan $\mathrm{r}=0,15 ; p=0,230)$. Konsentrasi ADMA dan hsCRP juga tidak berhubungan dengan kebiasaan minum kopi $(\mathrm{r}=0,03$; 
consumption only showed significant correlation with F2 isoprostane $(\mathrm{r}=0.34 ; p=0.004)$.

CONCLUSION: BP was not affected by coffee consumption although coffee consumption has a significant correlation with F2 isoprostane. These findings suggest that correlation between coffee consumption and BP might be explained by other factors that were not included in this study.

KEYWORDS: coffee, caffeine, cardiovascular disease, blood pressure, oxidative stress, inflammation, endothelial dysfunction

Indones Biomed J. 2013; 5(1): 51-8 $p=0,764$ dan $\mathrm{r}=0,04 ; p=0,701)$. Kebiasaan minum kopi hanya menunjukan hubungan yang bermakna dengan F2 isoprostan $(\mathrm{r}=0,34 ; p=0,004)$.

KESIMPULAN: TD tidak dipengaruhi oleh kebiasaan minum kopi meskipun kebiasaan minum kopi memiliki hubungan bermakna dengan F2 isoprostan. Hasil penelitian ini menunjukan bahwa hubungan antara kebiasaan minum kopi dengan peningkatan TD mungkin disebabkan oleh faktor lain yang tidak dianalisis dalam penelitian ini.

KATA KUNCI: kopi, kafein, penyakit kardiovaskular, tekanan darah, stres oksidatif, inflamasi, disfungsi endotel

\section{Introduction}

Coffee is the most widely consumed beverage in the world and is the main source of caffeine. Coffee has been widely consumed for centuries for its psychostimulant effect. Coffee exposure may actually take place since before birth, as caffeine can cross the placenta barrier, and it continues throughout adulthood life.(1,2) Considering its extensive use and public health importance, it is necessary that a study on the effects of coffee consumption on blood pressure (BP) and cardiovascular disease (CVD) be carried out.

Coffee contains several biologically active substances which have various effects, either harmful or beneficial on the cardiovascular system. Cafestol and kahweol, a diterpenoid alcohol compound present in unfiltered coffee brews have been known as hypercholesterolemic compounds. The chlorogenic acid, flavonoids, melanoidins and various lipidsoluble compounds such as furans, pyrroles and maltol are well absorbed and have been shown to have antioxidant properties. In some populations coffee is the main source of antioxidant.(3-6)

Caffeine (1,3,7-timethylxanthine) is the best characterized compound in coffee. More than $80 \%$ of the world's population ingests caffeine daily that is mostly derived from coffee, tea and caffeinated soft drinks. Caffeine is rapidly absorbed from gastrointestinal tract into the blood stream. Approximately 90\% of caffeine is cleared from stomach after 20 minutes. Peak plasma concentration is reached within 40-60 minutes. The structure of caffeine is similar to that of adenosine, therefore the main mechanism of action is antagonistic to adenosine. Caffeine occupies the adenosine receptor sites, especially $\mathrm{A} 1$ and $\mathrm{A} 2 \mathrm{a}$, thereby blocking the regulatory effect of adenosine. Thus the effect of caffeine is broadly stimulatory. $(1,3,7,8)$

Reports of adverse cardiovascular effects of caffeine have suggested it an important issue underlying the association between coffee and CVD. Researchers have examined the effects of coffee/caffeine consumption on $\mathrm{BP}$ and risk of CVD. The results were inconsistent and still remain a subject of controversy. Cohort studies generally have not supported a significant association between coffee consumption and CVD. Case control studies tend to support a significant association between coffee consumption and risk of CVD. $(1,3,9)$ A meta-analysis of 16 studies conducted by Noordzij et al.(10) showed an elevation of $2.04 \mathrm{mmHg}$ for systolic BP (SBP) and of $0.73 \mathrm{mmHg}$ for diastolic BP (DBP).

Several mechanisms have been proposed to explain the association between coffee consumption and the risk of CVD. The potential mechanisms include the effect of caffeine on BP, elevated cholesterol and homocysteine level, oxidative stress, inflammation and endothelial dysfunction(3), which still are not very clear. The aim of this study was to examine the relationship between habitual coffee consumption on BP and to examine the mechanism underlying the relationship.

\section{Methods}

\section{Study design}

This was a cross-sectional study. Forty-seven healthy, nonsmoking men aged 30-60 years with varying coffee-drinking habits were recruited. All subjects gave informed consent to participate in the study. Ethical approval was obtained from Health Research Ethics Committee, Faculty of Medicine, University of Hasanuddin, Makassar. Data were collected from January to March 2008. 


\section{Subjects}

The study subjects were recruited from patients who came to Prodia Clinical Laboratory, Denpasar, for having general medical check-up, as well as Prodia's employees. All subjects were apparently in good health conditions and willing to participate in the study. Subjects who had been consuming antioxidant supplement for the last 3 months, consumed anti-inflammatory drugs, had kidney dysfunction (glomerular filtration rate (GFR) $<60 \mathrm{~mL} / \mathrm{min}$ ), were diabetic (fasting glucose $\geq 126 \mathrm{mg} / \mathrm{dL}$ ), had hypertension (SBP $\geq 140 \mathrm{mmHg}, \mathrm{DBP} \geq 90 \mathrm{mmHg}$ and/or treated with antihypertensive drugs) and acute inflammation (high sensitive C-reactive protein (hsCRP) $>10 \mathrm{mg} / \mathrm{dL}$ ), were excluded from the study. Subjects with a waist circumference (WC) of more than $90 \mathrm{~cm}$ and were current smokers were also excluded from the study.

\section{Demographic data and questionnaire}

All tests were conducted in the morning, prior to any physical activity. After the consent process, all subjects were ask to fill in a questionnaire. The questionnaire was used to assess subject's demographic data, past medical history, dietary intake and coffee-drinking habit. The coffeedrinking habit was categorized into four groups: non-coffee, light/occasional coffee ( $\leq 1$ cup/day), moderate coffee (2-3 cups/day) and heavy coffee ( $>3$ cups/day) drinkers.

\section{BP measurement}

BP was measured using calibrated sphygmomanometer. Subjects were seated for at least 5 minutes prior to measurement. The first Korotkoff sound represents SBP and the fifth Korotkoff sound represents DBP. Three measurements were taken at 5 minutes interval. The average of the second and third measurement was used.

\section{Anthropometric measurement}

Body weight (BW) was measured in kilograms to the nearest $0.1 \mathrm{~kg}$. Height was measured in centimeters to the nearest $0.1 \mathrm{~cm}$. WC was measured in centimeters to the nearest 0.1 $\mathrm{cm}$ using a flexible non-elastic tape (Roche, Switzerland). WC was measured at the midway region between the lowest rib margin and the iliac crest, in standing position, abdomen relaxed, feet close together and weight equally divided over both legs.

\section{Blood analysis}

Fasting blood and first/second urine samples were collected in the morning after the subjects had completed the questionnaire and anthropometric measurement. Serum was used for analysis of fasting blood glucose, creatinine,
hsCRP, and asymmetric dimethylarginine (ADMA). Plasma ethylenediaminetetraacetic acid (EDTA) was used for caffeine analysis. Glucose and creatinine levels were determined using reagent from Roche Diagnostic (Roche Diagnostic GmBH, Switzerland). hsCRP was determined using high-sensitivity chemiluminescent assay on Immulite Instrument (DPC, Los Angeles, CA). ADMA was determined using enzyme immunoassay for the quantitative determination of endogenous asymmetric dimethylarginine (DLD Diagnostic GmBH, Germany). Caffeine was determined by high-performance liquid chromatography (HPLC) method. Urine was used for F2 isoprostane analysis. F2 isoprostane was determined by enzyme linked immunosorbent assay (ELISA) method (Oxford Biomedical Research, Oxford, MI).

\section{Data Analysis}

Data analysis was done using SPSS 11.5 (SPSS Inc, Chicago, IL). Distributions of continuous variable were assessed for normality using Kolmogorov-Smirnov. The differences between variables were analyzed using ANOVA and the correlations between variables were analyzed using Kendall's Tau correlation analysis. All tests were two-sided and considered significant at $p<0.05$.

\section{Results}

Analysis of the data showed that from a total of 47 subjects, 12 subjects $(25.5 \%)$ were grouped as non coffee drinkers, 20 subjects $(42.6 \%)$ as light coffee drinkers and 15 subjects $(31.9 \%)$ as moderate coffee drinkers. No subjects were grouped as heavy coffee drinkers. Thirty-three subjects $(94.3 \%)$ were reported of having habitual coffee consumption for more than 1 year and 2 subjects (5.7\%) for 1-12 months. Various demographic and clinical features of subjects are presented in Table1. Table 1 presents descriptive statistics for the different coffee drinkers groups (non, light and moderate coffee drinkers), while Table 2 present the difference between non coffee and coffee drinkers groups. Interestingly, data on the F2 Isoprostane concentrations showed marked differences between the groups (Table 2), but not significant (Table 2).

Correlation results between variables using Kendall's Tau correlation analysis are shown in Table 3. hsCRP values were $\log$ transformed because of their skewed distribution. Our results showed that coffee drinking habit was not correlated with SBP, DBP, $\log$ hsCRP and ADMA. Although not significantly correlated, SBP, DBP, and levels of hsCRP were higher in coffee drinkers group compared with non- 
coffee drinkers group (110.93 \pm 9.57 vs. 108.13 \pm 9.89 ; $75.41 \pm 6.30$ vs. $72.08 \pm 7.82$ and $1.397 \pm 1.72$ vs. $0.934 \pm 0.55$, respectively) (Table 2 ). Coffee drinking habit was found significantly correlated with caffeine $(\mathrm{r}=0.23, p=0.049)$ and $\mathrm{F} 2$ isoprostane concentration $(\mathrm{r}=0.34, p=0.004)$.

\section{Discussion}

The aim of this study was to examine the relationship between the effects of habitual coffee consumption on BP and to examine the role of oxidative stress (F2 isoprostane), inflammation (hsCRP) and endothelial dysfunction (ADMA). We found that BP was not correlated with coffee consumption. This findings support the previously reported cohort studies.

A cohort study by Winkelmayer et al.(11) showed that there was no correlation between coffee consumption and hypertension in 155,549 United States of America women followed up over 12 years. Lopez-Garcia et al.(12) also showed that no correlation was found between coffee consumption and CVD in 44,005 men and 84,488 women followed up for 2-4 years. Klag et al.(13) reported that coffee consumption was associated with small increases in BP and played a small role in the development of hypertension.

In contrast with the result of cohort studies, a randomized clinical trial with cross over conducted by Lovallo et al.(14) showed that caffeine acutely increased BP after 5 days of intervention. The effect was greater in people at high-risk of hypertension and was prolonged in those with confirmed hypertension. Hartley et al.(15) also found similar results. The caffeine was acutely increasing $\mathrm{BP}$ and exerting greater BP effects on those with a greater risk of hypertension.

Caffeine is rapidly absorbed from the stomach. Approximately $99 \%$ of caffeine is cleared from the stomach within 45 minutes and peak plasma concentration is reached within 15-120 minutes. However the absorption is not complete when caffeine is taken as coffee.(16) In this study, BP measurements and blood biomarkers assessments were performed in the morning after overnight (10-12 hour) fasting. The average abstinence time for light coffee drinker s group was $20.70 \pm 6.60$ hours and $18.17 \pm 4.30$ hours for moderate coffee drinkers group. Caffeine concentrations were found to be $0.084 \mu \mathrm{g} / \mathrm{mL}, 0.197 \mu \mathrm{g} / \mathrm{mL}$ and 0.377 $\mu \mathrm{g} / \mathrm{mL}$, for non, light and moderate coffee drinkers group,

Table 1. Subjects Characteristics of Non, Light and Moderate Coffee Drinkers Groups.

\begin{tabular}{lcccc}
\hline \multirow{2}{*}{ Variable } & \multicolumn{3}{c}{ Coffee Drinkers Group } & p \\
\cline { 2 - 4 } & Non & Light & Moderate & - \\
\hline $\mathrm{n}$ & $12(25.5 \%)$ & $20(42.6 \%)$ & $15(31.9 \%)$ & 0.792 \\
Age (year) & $39.750 \pm 8.040$ & $40.250 \pm 7.960$ & $41.730 \pm 8.200$ & 0.470 \\
Height $(\mathrm{cm})$ & $167.402 \pm 6.760$ & $167.700 \pm 5.510$ & $165.130 \pm 7.120$ & 0.642 \\
Weight $(\mathrm{kg})$ & $68.710 \pm 5.780$ & $66.230 \pm 7.280$ & $67.100 \pm 8.040$ & 0.908 \\
WC $(\mathrm{cm})$ & $82.920 \pm 4.930$ & $83.630 \pm 5.390$ & $83.730 \pm 5.060$ & 0.108 \\
SBP $(\mathrm{mmHg})$ & $108.130 \pm 9.890$ & $113.630 \pm 6.760$ & $107.330 \pm 11.670$ & 0.348 \\
DBP $(\mathrm{mm} \mathrm{Hg})$ & $72.080 \pm 7.820$ & $75.350 \pm 5.600$ & $75.500 \pm 7.330$ & 0.231 \\
Abstinence & - & $20.700 \pm 6.600$ & $18.170 \pm 4.300$ & $0.049 *$ \\
Caffeine $(\mu \mathrm{g} / \mathrm{mL})$ & $0.084 \pm 0.090$ & $0.197 \pm 0.210$ & $0.377 \pm 0.470$ & \\
F2 isoprostane & & & & \\
(pg F2 / mg Creatinine) & $84.770 \pm 38.830$ & $74.900 \pm 23.480$ & $119.810 \pm 32.220$ & $<0.001 * *$ \\
hsCRP $(\mathrm{mg} / \mathrm{L})$ & $0.934 \pm 0.550$ & $1.564 \pm 2.140$ & $1.174 \pm 0.930$ & 0.507 \\
ADMA $(\mu \mathrm{mo} / \mathrm{L})$ & $0.678 \pm 0.080$ & $0.693 \pm 0.130$ & $0.696 \pm 0.140$ & 0.924 \\
\hline
\end{tabular}

Values are shown as mean \pm standard deviation. *significant at $p<0.05, * *$ significant at $p<0.01$ 
Table 2. Subjects Characteristics of Non Coffee and Coffee Drinkers Groups.

\begin{tabular}{|c|c|c|c|}
\hline \multirow{2}{*}{ Variable } & \multicolumn{2}{|c|}{ Group } & \multirow{2}{*}{$p$} \\
\hline & Non Coffee Drinkers & Coffee Drinkers & \\
\hline $\mathrm{n}$ & $12(25.5 \%)$ & $20(42.6 \%)$ & - \\
\hline Age (year) & $39.750 \pm 8.040$ & $40.890 \pm 7.980$ & 0.673 \\
\hline Height (cm) & $167.420 \pm 6.760$ & $166.600 \pm 6.280$ & 0.705 \\
\hline Weight (kg) & $68.710 \pm 5.780$ & $66.600 \pm 7.510$ & 0.381 \\
\hline $\mathrm{WC}(\mathrm{cm})$ & $82.920 \pm 4.930$ & $83.670 \pm 5.170$ & 0.661 \\
\hline SBP (mm Hg) & $108.130 \pm 9.890$ & $110.930 \pm 9.570$ & 0.39 \\
\hline DBP (mm Hg) & $72.080 \pm 7.820$ & $75.410 \pm 6.300$ & 0.144 \\
\hline Caffeinqu( g/mL) & $0.084 \pm 0.090$ & $0.274 \pm 0.360$ & 0.076 \\
\hline $\begin{array}{l}\text { F2 isoprostane } \\
\text { (pg F2 / mg Creatinine) }\end{array}$ & $84.770 \pm 38.830$ & $94.140 \pm 35.270$ & 0.443 \\
\hline hsCRP (mg/L) & $0.934 \pm 0.550$ & $1.397 \pm 1.720$ & 0.367 \\
\hline $\operatorname{ADMA}(\mu \mathrm{mol} / \mathrm{L})$ & $0.678 \pm 0.080$ & $0.694 \pm 1.130$ & 0.694 \\
\hline
\end{tabular}

Values are shown as mean \pm standard deviation.

Table 3. Correlation Coefficients of Non Coffee vs. Coffee Drinkers Groups and Among All Variables.

\begin{tabular}{lccccc}
\hline \multirow{2}{*}{ Variable } & Coffee Drinkers Groups & Caffeine & F2 isoprostane & Log hsCRP & ADMA \\
\cline { 2 - 6 } & $\mathbf{r}$ & $\mathbf{r}$ & $\mathbf{r}$ & $\mathbf{r}$ & $\mathbf{r}$ \\
\hline Age & - & - & -0.01 & -0.01 & $0.24^{*}$ \\
SBP & -0.02 & -0.25 & -0.19 & -0.15 & -0.07 \\
DPB & 0.15 & 0.21 & 0.03 & -0.12 & -0.17 \\
Caffeine & $0.23^{*}$ & 1 & 0.13 & 0.01 & -0.03 \\
F2 isoprostan & $0.34^{* *}$ & 0.13 & 1 & -0.03 & -0.06 \\
Log hsCRP & 0.04 & 0.01 & -0.03 & 1 & 0.19 \\
ADMA & 0.03 & -0.03 & -0.06 & 0.19 & 1 \\
\hline
\end{tabular}

*significant at $p<0.05, * *$ significant at $p<0.01$.

respectively (Table 1). Those concentrations are far below the therapeutic dose of caffeine (8.0-20.0 $\mu \mathrm{g} / \mathrm{mL})$.(17) Interestingly, caffeine was also found in the sample of noncoffee drinkers group, suggesting that these subjects might have been having caffeine-contained meals or drinks other than coffee, possibly tea or caffeinated soft-drinks.

The correlation between coffee consumption and BP may greatly depend on the time lag between exposure/ consumption and BP measurements. The influence of coffee consumption (caffeine) on BP may vary from zero when plasma caffeine levels are depleted to several $\mathrm{mmHg}$ when plasma caffeine has been replenished. An overnight abstinence may lead to only modest increases in BP. An acute effect of caffeine may also explain the conflicting result of the many studies relating to coffee consumption and BP. Studies with shorter follow-up periods may report 
positive effect compared to longer follow-up period. $(1,3,18,19)$ The studies conducted by Mesas et al.(20), Zampelas et al.(21), and Papamichael et al.(22) also showed that habitual (chronic) coffee consumption only have little effect on BP and biomarker, whereas the acute consumption have more significant effect on BP and biomarker.

In this study, blood collection was performed after one night fasting. Overnight fasting caused the caffeine concentration to get back to normal. This might be the reason why coffee consumption showed no correlation with BP, hsCRP and ADMA concentrations. Although not significantly correlated, BP among coffee drinkers was higher than that among non coffee drinkers; 110.93 vs. $108.13 \mathrm{mmHg}$ for $\mathrm{SBP}$ and $75.41 \mathrm{vs} .72 .08 \mathrm{mmHg}$ for DBP, respectively (Table 2). BP reduction even in a modest amount has the potential to reduce morbidity and mortality in general population, or at least it can delay the onset of hypertension. It has been estimated that a decrease of $2 \mathrm{mmHg}$ in SBP would result in lower mortality of approximately $7 \%$ for coronary heart disease (CHD) and 10\% for stroke.(23) The Seventh Report of the Joint National Committee on Prevention, Detection, Evaluation, and Treatment of High Blood Pressure (JNC VII) estimated that a decrease in the SBP of $5 \mathrm{mmHg}$ would result in $14 \%$ overall reduction in mortality due to stroke, a $9 \%$ due to CHD and a $7 \%$ due to all cause mortality.(24)

Although there was no significant correlation, the hsCRP concentrations in coffee drinkers $(1.397 \mathrm{mg} / \mathrm{L}, 95 \%$ CI: 0.806-1.987) were higher than in non-coffee drinkers (0.934 mg/L, 95\% confidence interval (CI): 0.584-1.284) (Table 2). There is a consensus that hsCRP level $<1 \mathrm{mg} / \mathrm{L}$ is correlated with low risk of CVD, while hsCRP level 1-3 $\mathrm{mg} / \mathrm{L}$ is correlated with moderate risk of CVD. This result suggests that coffee consumption might increase the risk of CVD.

Habitual coffee consumption was significantly correlated with F2 isoprostane concentrations $(\mathrm{r}=0.34$, $p=0.004)$. The mean of $\mathrm{F} 2$ isoprostane concentration among non, light and moderate coffee drinkers groups are $84.77 \pm$ $28.83,74.90 \pm 23.48$ and $119.81 \pm 32.22$, respectively. The relatively low correlation $(\mathrm{r}=0.34)$ between habitual coffee consumption and F2 isoprostane was related to its non-linier correlation. We found a U-shaped correlation between coffee consumption and F2 isoprostane concentration. The lowest F2 isoprostane concentration was at light coffee drinkers group and increased in moderate coffee drinkers group as well as in non-coffee drinkers group. Other studies also found similar result on the correlation between coffee consumption and the risk of CVD. They found that moderate coffee drinkers group had the lowest incidence of coronary event compared to non and heavy coffee drinkers group.(12, 19, 25-29)

Coffee has unique biological and metabolic properties. Coffee is a complex mixture of harmful and beneficial compounds. The chlorogenic acid, flavonoids, melanoidins and various lipid-soluble compounds such as furans, pyrroles and maltol are some compounds that have beneficial effects (antioxidant). Epidemiological studies have found that in some populations coffee is the main source of antioxidant. $(6,25)$ The antioxidant compounds in coffee are absorbed rapidly after ingestion which may lead to the elevated level of antioxidant in circulation. On the other hand, caffeine increases angiotensin II production by inhibiting adenosine A1 receptor on the production of renin.(22) The balance between pro-oxidative and antioxidant compounds in coffee may be an important factor that determines its effects on blood pressure and biological markers, which needs to be elaborated further.(30)

The conflicting result of the many studies relating to coffee consumption and BP may be due to inadequate adjustment of confounding variables. Coffee consumption has become part of modern life-style, together with smoking and alcohol consumption. More than $50 \%$ of women and $30 \%$ of men who drink coffee at least 6 cups/day also smoke cigarette. Caffeine's half-life is reduced by $30-50 \%$ in smoker compared to non smoker.(10,16) Smoking habit was excluded in this study. We also adjusted the other confounding factors, such as sex, age, alcohol consumption, WC, medical history (acute inflammation, hypertension, diabetes, renal failure), and dietary factors (antioxidant/ vitamin/energy drinks consumption).

The method of coffee preparation (boiled, filtered), the type of coffee (black coffee, instant coffee), varieties of coffee (arabica, robusta) and the exact amounts of coffee ingested are also important confounding factors that may affect the outcome of the study. However, in this study we did not adjust those factors.

More than $95 \%$ caffeine metabolism in the liver is mediated by cytochrome P450 (CYP) 1A2. The large variability of the enzyme is responsible for the interindividual variability in caffeine metabolism. The genetic modifier of exposure and the genetic of biological effect may play an important role in the correlation between coffee consumption and CVD.(31) This remains an issue to be further elaborated.

It is also important to note that this research, being a cross sectional study, posses various limitations. Therefore, a further study needs to be carried out with a greater number of subjects, diverse coffee drinking habits categories (non, low, moderate, heavy coffee drinkers), and involving assessment of genetic polymorphism in CYP1A2 enzyme. 


\section{Conclusion}

Habitual coffee consumption does not correlate with BP although it has partial correlation with F2 isoprostane. These findings suggest that correlation between coffee consumption and BP might be explained by other confounding factors.

\section{Acknowledgement}

We thank Mr. Andi Wijaya and Prodia Education and Research Institute for their funding and other supports of this study. We also thank the staff of Prodia Clinical Laboratory, Denpasar for their participation in sample and data collection.

\section{References}

1. James JE. Critical review of dietary caffeine and blood pressure: a relationship that should be taken more seriously. Psychosom Med. 2001; 66: 63-71.

2. Van't Hoff W. Caffeine in Pregnancy. Lancet. 1982; 2:1020.

3. Cornelis MC, El-Sohemy A. Coffee, Caffeine, and Coronary Heart Disease. Curr Opin Lipidol. 2007; 18: 13-9.

4. Ricketts ML, Boekschoten MV, Kreeft AJ, Hooiveld GJEJ, Moes CJA, Müller M, et al. The Cholesterol-Raising Factor from Coffee Beans, Cafestol, as an Agonist Ligand for the Farnesoid and Pregnane X Receptors. Mol Endocrinol. 2007; 21(7): 1603-16.

5. Svilaas A, Sakhi AK, Andersen LF, Svilaas T, Strom EC, Jacobs Jr DR, et al. Intakes of Antioxidants in Coffee, Wine, and Vegetables Are Correlated With Plasma Carotenoids in Humans. J Nutr. 2004; 134: 562-67.

6. Olthof MR, Hollman PC, Katan MB. Chlorogenic Acid and Caffeic Acid are Absorbed in Humans. J Nutr. 2001; 131: 66-71.

7. Brown RD, Thorén P, Steege A, Mrowka R, Sällström J, Skøtt O, et al. Influence of The Adenosine A1 Receptor on Blood Pressure Regulation and Renin Release. Am J Physiol Regul Integr Comp Physiol. 2006; 290: R1324-9.

8. Varani K, Portaluppi F, Gessi S, Merighi S, Ongini E, Belardinelli L, et al. Dose and Time Effects of Caffeine Intake on Human Platelet Adenosine A2A Receptor: Functional and Biochemical Aspects. Circulation. 2000; 102: 285-9.

9. Hamer M. Coffee and Health: Explaining Conflicting Results in Hypertension. J Hum Hypertens. 2006; 20: 909-12.

10. Noordzij M, Uiterwaal CS, Arends LR, Kok FJ, Grobbee DE, Geleijnse JM. Blood Pressure Response to Chronic Intake of Coffee and Caffeine: A Meta-Analysis of Randomized Controlled Trials. J Hypertens. 2005; 23:921-8.

11. Winkelmayer WC, Stampfer MJ, Willett WC, Curhan GC. Habitual Caffeine Intake and the Risk of Hypertension in Woman. JAMA. $2005 ; 294: 2330-5$.

12. Lopez-Garcia E, Dam van RM, Willett WC, Rimm EB, Manson JE, Stampfer MJ, et al. Coffee Consumption and Coronary Heart Disease in Men and Women: A Prospective Cohort Study. Circulation. 2006; 113: 2045-53.
13. Klag MJ, Wang NY, Meoni LA, Brancati FL, Cooper LA, Liang KY, et al. Coffee Intake and Risk of Hypertension, the John Hopkins Precursor Study. Arch Intern Med. 2002; 162: 657-62.

14. Lovallo WR, Wilson MF, Vincent AS, Sung BH, McKey BS, Whitsett TL. Blood Pressure Response to Caffeine Shows Incomplete Tolerance after Short-Term Regular Consumption. Hypertension. 2004; 43: 760-5.

15. Hartley TR, Sung BH, Pincomb GA, Whitsett TL, Wilson MF, Lovallo WR. Hypertension Risk Status and Effect of Caffeine on Blood Pressure. Hypertension. 200; 36: 137-41.

16. Fredholm BB, Battig K, Holmen J, Nehlig A, Zvartau EE. Actions of Caffeine in the Brain with Special Reference to Factors That Contribute to Its Widespread Use. Pharmacol Rev. 1999; 51: 83133.

17. Pesce AJ, Rashkin M, Kotagal U. Standard of laboratory practice: theophylline and caffeine monitoring. National Academy of Clinical Biochemistry. Clin Chem. 1988; 44(5): 1126-8.

18. Myers MG, Champagne CM. Nutritional Effects on Blood Pressure. Curr Opin Lipidol. 2007; 18: 20-4.

19. Happonen P, Voutilainen S, Salonen JT. Coffee Drinking Is DoseDependently Related to The Risk of Acute Coronary Events in Middle-Aged Men. J Nutr. 2004; 134: 2381-6.

20. Mesas AE, Leon-Muñoz LM, Rodriguez-Artalejo F, Lopez-Garcia E. The Effect of Coffee on Blood Pressure and Cardiovascular Disease in Hypertensive Individuals: A Systematic Review and MetaAnalysis. Am J Clin Nutr. 2011; 94: 1113-26.

21. Zampelas A, Panagiotakos DB, Pitsavos C, Chrysohoou C, Stefanadis C. Associations Between Coffee Consumption and Inflammatory Markers in Healthy Persons: The ATTICA Study. Am J Clin Nutr. 2004; 80: 862-7.

22. Papamichael CM, Aznaouridis KA, Karatzis EN, Karatzi KN, Stamatelopoulos KS, Vamvakou G, et al. Effect of Coffee on Endothelial Function in Healthy Subjects: The Role of Caffeine. Clin Sci (Lond). 2005; 109: 55-60.

23. Prospective Studies Collaboration. Age-Specific Relevance of Usual Blood Pressure to Vascular Mortality: A Meta Analysis of Individual Data for One Million Adults in 61 Prospective Studies. Lancet. 2002; 360: 1903-13.

24. Chobanian AV, Bakris GL, Black HR, Cushman WC, Green LA, Izzo $\mathrm{JL}$, et al, and The National High Blood Pressure Education Program Coordinating Committee. Seventh Report of the Joint National Committee on Prevention, Detection, Evaluation, and Treatment of High Blood Pressure. JNC 7-Complete Report. Hypertension. 2003; 42: 1206-52.

25. Andersen LF, Jacobs DR, Carlsen MH, Blomhoff R. Consumption of Coffee Is Associated With Reduced Risk of Death Attributed to Inflammatory and Cardiovascular Disease in The Iowa Woman's Health Study. Am J Clin Nutr. 2006; 83: 1039-46.

26. Hamer M, Williams ED, Vuononvirta R, Gibson EL, Steptoe A. Association Between Coffee Consumption and Markers of Inflammation and Cardiovascular Function During Mental Stress. J Hypertens. 2006; 24: 2191-7.

27. Panagiotakos DB, Pitsavos C, Chrysohoou C, Kokkinos P, Toutouzas P, Stefanadis C. The J-Shaped Effect of Coffee Consumption on the Risk of Developing Acute Coronary Syndromes: The CARDIO2000 Case Control Study. J Nutr. 2003; 133: 3228-32.

28. Silletta MG, Marfisi RM, Levantesi G, Boccanelli A, Chieffo C, Franzosi MG, et al. Coffee Consumption and Risk of Cardiovascular Events After Acute Myocardial Infarction-Result From the GISSI Prevenzione Trial. Circulation. 2007; 116: 2944-51.

29. Uiterwaal CS, Verschuren WM, Bueno-de-Mesquita HB, Ocké M, Geleijnse JM, Boshuizen HC, et al. Coffee Intake and Incidence of Hypertension. Am J Clin Nutr. 2007; 85: 718-23.

30. Mayorov DN. Does Coffee Reinforce the Vascular Inflammatory 
Response to Mental Stress? J Hypertens. 2006; 24: 2149-51.

31. Cornelis MC, El-Sohemy A, Kabagambe EK, Campos H. Coffee, CYP1A2 Genotype, and Risk of Myocardial Infarction. JAMA. 2006; 295: 1135-41. 